\title{
DOROTHY ATKINSON
}

\section{The Statistics on the Russian Land Commune, 1905-1917}

Western and Soviet scholars have generally maintained different interpretations of the period between 1905 and 1917 in Russia, describing it respectively as a time of amelioration or of immiseration for the masses. Both groups, however, have stressed the progress of capitalism in prerevolutionary Russia. Despite standard references to the agrarian problem, most of the attention given to socioeconomic development in this period has focused on industrialization and the urban sector. Yet 87 percent of the population was rural when revolution broke out in 1905, and 85 percent still rural when it erupted again in 1917.

During the interrevolutionary period the imperial government adopted a program that was intended to provide a take-off base for agriculture. Prime Minister Stolypin's policy was aimed at the replacement of the archaic communal structure by a new order of individualized peasant landholdings that would give scope to personal initiative and technological innovation. A direct legislative and administrative assault on the commune was launched. New Land Organization Commissions were to provide technical assistance in the establishment of individual farms and the rationalization of group holdings. The property and credit resources of the Peasant Land Bank were substantially extended to encourage individualization and modernization.

Though they differ about its significance, Soviet and Western scholarsrelying on the same statistics-have been in fair agreement on the extent of the government's achievement in eradicating the commune. Lenin, who had slight sympathy for this favorite populist institution, felt that the anticommunal policy of "agrarian Bonapartism" might well succeed. ${ }^{1}$ Despite criticism of the Stolypin reform, many Soviet works indicate that the tsarist government made substantial progress against the commune. One authority noted

1. V. I. Lenin, Polnoe sobranie sochinenii, 55 vols. (Moscow, 1958-65), 17:275. Lenin considered the commune an economic anachronism but one with redeeming features. His views on the commune are traced by V. P. Danilov, " $K$ voprosu o kharaktere i znachenii krest'ianskoi pozemel'noi obshchiny $\vee$ Rossii," Problemy sotsial'no-ekonomicheskoi istorii Rossii: Sbornik statei (Moscow, 1971), pp. 341-59.

The author would like to acknowledge the research support of the National Fellows Program of the Hoover Institution on War, Revolution and Peace. 
not long ago that there was still an opinion among Soviet historians that the commune had ceased to exist before the October Revolution. ${ }^{2}$

Land statistics for 1905 show 77 percent of the peasantry of European Russia in communes. ${ }^{3}$ The view that noncommunal tenure predominated by the time of the Revolution has been presented in Soviet literature for half a century. ${ }^{4}$ By 1917 , according to some sources, 41 percent of the peasants had left the commune. ${ }^{5} \mathrm{~A}$ recent two-volume Soviet agrarian history places 43 percent of the peasants in communes in 1917. ${ }^{6}$ Emigré scholars tended to confirm the impression created by those Russian and foreign contemporaries of the reform who found it an "immense and unqualified success." Given enough time, they indicated, the agrarian revolution from above offered a viable alternative to revolution from below. The most serious Western attempt to grapple with the tangled statistical data on peasant departures from communes led one conscientious scholar to the widely echoed conclusion that "more than half of the peasantry was non-communal a decade after 1905" and by a different reckoning "far more than half." Many Western writers who share his cautious appraisal of the reform state similarly that only a minority of the peasantry remained in communes by $1917 .{ }^{\circ}$ These views, though typical, are not necessarily universal, and often are maintained with reservations. Yet

2. S. P. Trapeznikov, Leninizm $i$ agrarno-krestianskii vopros, 2 vols. (Moscow, 1967), 1:372.

3. Ministerstvo Vnutrennikh Del, Tsentral'nyi statisticheskii komitet, Statistika zemlevladeniia 1905 g.: Svod dannykh po 50 guberniiam Evropeiskoi Rossii (St. Petersburg, 1907), p. 175.

4. Krest'ianskaia sel'sko-khoziaistvennaia entsiklopediia, vol. 2-3: Ekonomika i blagoustroistva dereuni (Moscow and Leningrad, 1925), p. 324.

5. N. P. Oganovsky, Revoliutsiia naoborot (Ragrushenie obshchiny) (Petrograd, 1917), p. 99; S. M. Dubrovsky, Stolypinskaia reforma (Leningrad, 1925), p. 108; P. I. Liashchenko, Istoriia russkogo narodnogo khoziaistva (Moscow and Leningrad, 1927), p. 492 ; Trapeznikov, Leninizm, 1:203.

6. P. N. Pershin, Agrarnaia revoliutsiia v Rossii, 2 vols. (Moscow, 1966), 1:98-99.

7. Michael T. Florinsky, The End of the Russian Empire (New Haven, 1931), p. 16; Florinsky uses the phrase quoted to describe the appraisals of others; his own opinion was qualified. See also Alexander D. Bilimovich, "The Land Settlement in Russia and the War," Russian Agriculture During the War (New Haven, 1930), pp. 342-43; George P. Pavlovsky, Agricultural Russia on the Eve of the Revolution (New York, 1968; first pub. 1930), pp. 134-35; Naum Jasny, The Socialized Agriculture of the USSR (Stanford, 1949), pp. 141-42.

8. Geroid Robinson, Rural Russia Under the Old Regime (Berkeley and Los Angeles, 1967; first pub. 1932), pp. 215-16.

9. For example, Richard Charques, The Twilight of Imperial Russia (London, 1965; first pub. 1958), pp. 178-79; Maurice Dobb, Soviet Economic Development Since 1917 (New York, 1966), p. 55; Theodore Von Laue, Why Lenin? Why Stalin? (Philadelphia and New York, 1964), p. 72; Lazar Volin, "Agrarian Individualism in the Soviet Union: Its Rise and Decline," Part 1, Agricultural History, January 1938, p. 18. Volin later modified his position; see $A$ Century of Russian Agriculture (Cambridge, Mass., 1970), p. 105. 
the statistics on which they are based appear to be universally accepted, and the statistics can suggest that "approximately two-thirds of the peasant households of all Russia had been converted into private property in the decade from 1906 to 1916."10 In view of such general consensus, a substantial decline of the commune might be considered an established fact, and a rapid demise of the institution a foregone conclusion. The course of the commune's postrevolutionary history, however, does violence to such anticipations. After 1917 communal tenure showed marked vitality. ${ }^{11}$ This apparent historical discontinuity suggests the need for a re-examination of the data on the commune between revolutions.

In fifty provinces of European Russia in 1905 there were 12.3 million peasant households. ${ }^{12}$ Of these, 9.5 million were in communes (obshchiny) holding their field lands in scattered strips that were redistributed periodically in accordance with the shifting size or labor supply of the member households. The remaining peasants held land under what was known as podvornoe (household) tenure, with each family holding a similar assortment of strips, but retaining them as hereditary property not subject to redistribution. In both communal and hereditary tenure, households kept the family dwelling and garden plot permanently, and in both types of community certain lands (generally pasture and meadow, often woods and waters) were held in common. Under the terms of the Emancipation and subsequent legislation, peasants in communes had been virtually locked into communal tenure. Following the revolution of 1905 new regulations were introduced (beginning with a decree of November 9,1906 ) encouraging the conversion of communal holdings into hereditary personal property. Once the land had been appropriated the peasant could oblige the commune to exchange his scattered strips for a consolidated single piece (or fewer pieces) of land.

From 1907 through 1915 approximately 2.7 million peasants filed applications for appropriation of communal land. Some 2 million appropriations had been effected by the end of the period. ${ }^{13}$ The gap between the number of applications and the number of separations completed was due apparently only in part to a processing lag. Only one-fourth of the applicants reached an agreement with the commune; the remainder required the assistance of the local authorities. Close to 10 percent of the applications were subsequently

10. Donald W. Treadgold, The Great Siberian Migration (Princeton, 1957), p. 49. The same conclusion was reached by V. A. Kosinsky in an unpublished manuscript now in the Hoover archives, "Russkaia agrarnaia revoliutsiia," pp. 547-48.

11. Tsentral'noe statisticheskoe upravlenie, Trudy, 8, pt. 1: Statisticheskii eahegodnik 1918-1920 gg. (Moscow, 1921), pp. 284-332; 8, pt. 5: Statisticheskii eahegodnik 1922 i $1923 \mathrm{gg}$. (Moscow, 1924), p. 181.

12. Statistika zemlevladeniia $1905 \mathrm{~g}$., pp. 174-75.

13. TsSK, Statisticheskii eshegodnik 1915, sec. 6:1. 
withdrawn by peasants. ${ }^{14}$ There is evidence that some peasants were reluctant to go through with separations prompted by zealous officials. On the other hand, some households were forcibly carried into hereditary tenure by the two-thirds vote of their commune. ${ }^{15}$ In one way or another, however, 2 million peasants became personal proprietors under the provisions and later extensions of the 1906 decree.

Applications for appropriation peaked in 1909 and declined rapidly thereafter. This has been taken as an indication of the release of the backlog of pressure from those who wanted to leave the commune (many of whom had already departed and could now formalize the fact) and from those who found it most profitable to appropriate. ${ }^{16}$ To some extent, however, the fall reflects the impact of new automatic conversion legislation.

A law of June 14, 1910, declared that all communes which had not held a general redistribution of allotment land in their possession since 1887 were to be recognized as being under hereditary tenure. Certificates of ownership were to be issued on request. The government estimated that at least 3.5 million households fell into this group, but by 1916 somewhat less than 500,000 households had been certified to be no longer under communal tenure. This included 317,000 households which had applied individually for certification, and a balance of 153,000 households listed on general certificates issued to communes applying as a whole. Some households in the latter group had already appropriated their land, so the two categories of separators overlap here. ${ }^{17}$ According to official instructions, the 1910 law was interpreted as applying only to those communes where a request was made for certification. The request of a single peasant, however, was declared sufficient to establish

14. N. I. Karpov, Agrarnaia politika Stolypina (Leningrad, 1925), fold-out table p. 203; S. M. Dubrovsky, Stolypinskaia zemel'naia reforma (Moscow, 1963), p. 581. Most writers agree that peasants were pressured to leave the commune, though some feel that the degree of compulsion has been exaggerated. For peasant complaints reported in a Free Economic Society survey see I. V. Chernyshev, Obshchina posle 9 noiabria $1906 \mathrm{~g}$. (Petrograd, 1917), passim.

15. One limited study showed that 40 percent of the households replying to an inquiry on motivation in this type of group conversion had opposed the change and another 6 percent simply "went along" with the majority. See I. V. Mozzhukhin, Zemleustroistvo v Bogoroditskom uezde Tul'skoi gubernii (Moscow, 1917), p. 158.

16. K. R. Kachorovsky, "The Russian Land Commune in History and Today," Slavonic and East European Revieve, 7 (1929) : 565-76.

17. Statisticheskï spravochnik po agrarnomu voprosu, pt. 1, ed. N. P. Oganovsky and A. V. Chaianov (Moscow, 1917), pp. 26-27; A. E. Lositsky, $K$ voprosy ob izuchenii stepeni i form raspadeniia obshchiny (Moscow, 1916), p. 8. No adequate record of communal redistributions had been kept, and the official estimate has been challenged. In any case, general redistributions were far less common than partial redistributions, and the absence of the former did not necessarily indicate an end of communal practices. Lositsky estimated (p. 53) that half a million of the peasants in the communes considered as nonredistributional had already appropriated their land before June 1910. 
the conversion of his entire commune to hereditary tenure. ${ }^{18}$ Through this blanketing procedure the 317,000 households who received individual certificates drew another 1.7 million of the eligible 3.5 million households into a tenuous juridical approximation to conversion.

By 1916, 2.5 million peasants (2 million appropriators and 500,000 certified personal proprietors) had fully individualized their titles to land under the new options. However, the land itself in the majority of cases remained just as before-in numerous narrow strips interspersed among neighbors' holdings and subject to the old three-field rotation practices of the community.

With the aid of the Land Organization agencies, 1.3 million consolidated farms were established on allotment lands from 1907 through $1916.1^{19}$ This included noncommunal as well as communal land. After May 1911 it was not necessary to appropriate land prior to consolidation. Since 800,000 of the consolidations on allotment land were made after that date, some of the peasants in the group of consolidators should probably be added to the total number of separators. Data available through 1911 show that three-quarters of all consolidations on allotment land were formed by peasants from communes. ${ }^{20}$ In other words, communal and noncommunal peasants consolidated at about the same rate, given the relative size of the two groups. Because of a change in statistical recording practices, the same type of data is not obtainable for later years; but if the pattern continued, former communal peasants may have accounted for 600,000 of the post-1911 consolidations (see chart 1). However, some of these peasants had individualized their land earlier, and some are included among later separators. As in other intersections of the various circles of separators, the overlap cannot be determined.

Despite such problems, lack of more precise information has required the use of the available data. On the assumption that at least some of the double countings and undercountings of the statistics balance out, the figure of 2.5 million documented separations has been widely used to gauge the effect of the reform on the commune.

18. A. A. Manuilov, "Noveishee zakonodatel'stvo o zemel'noi obshchine," Vestnik Evropy, November 1912, p. 248.

19. P. N. Pershin, Uchastkovoe zemlepol'zovanie v Rossii (Moscow, 1922), p. 8; an additional 300,000 were formed on lands of the Peasant Land Bank. Allotment lands were those turned over to the peasantry for redemption at the time of Emancipation; an unknown number of the 1.3 million consolidations generally described as "on allotment land" actually included nonallotment land, though apparently only a small quantity. See A. A. Kofod, Russkoe zemleustroistvo, 2nd ed. (St. Petersburg, 1914), p. 109.

20. Sovet s"ezdov predstavitelei promyshlennosti i torgovli, Statisticheskii ezhegodnik na 1913 god (St. Petersburg, 1913), p. 17. Text (p. 13) indicates that data here were taken from Glavnoe upravlenie zemleustroistva i zemledeliia, Obzor deiatel'nosti zemleustroitel'nykh komissii za 1907-1911 gg. 
Chart 1. Dynamics of Land Tenure Conversions

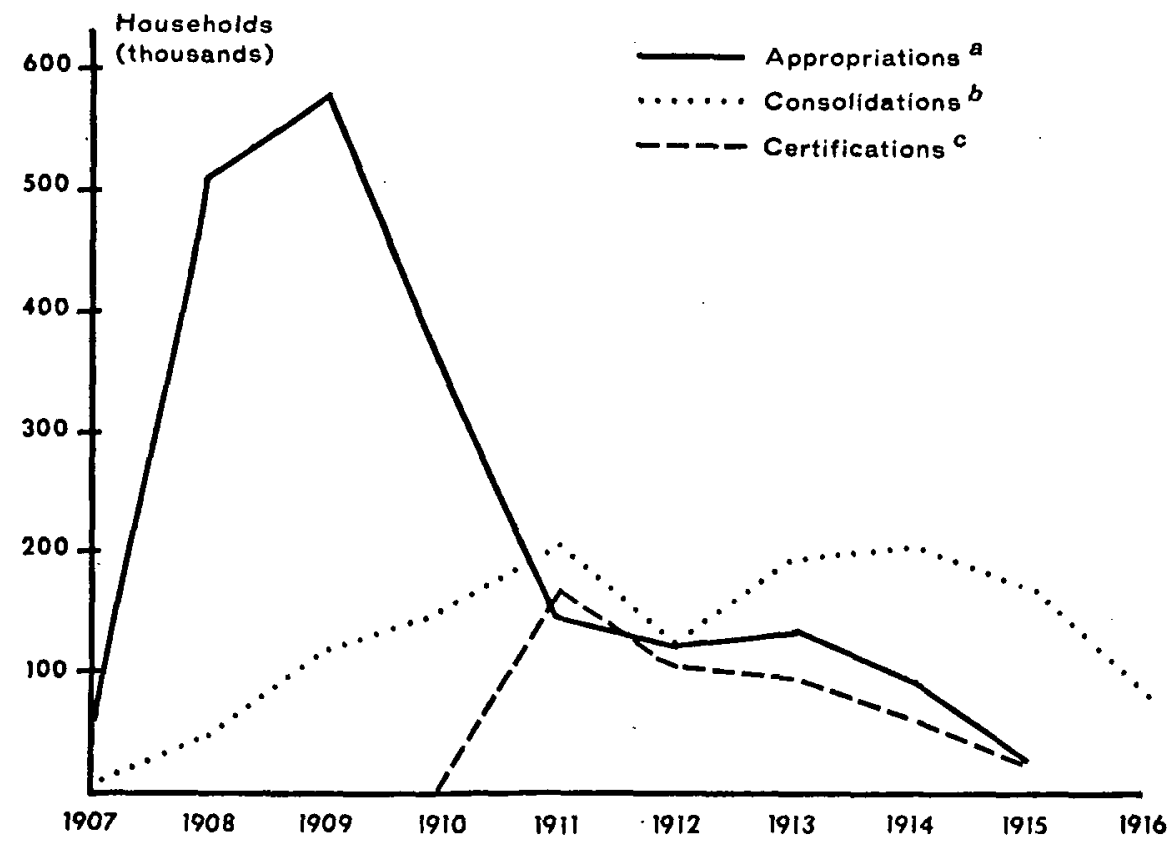

Sources: aI. V. Chernyshev, Obshchina posle 9 noiabria $1906 \mathrm{~g}$. (Petrograd, 1917), 1 :xiii. bP. N. Pershin, Uchastkovoe zemlepol'zovanie v Rossii (Moscow, 1922), p. 7; consolidations on allotment land. cTsGIAL, fond 1291, op. 121, 1916 g., d. 57, 1. 584a and d. 75, 1. 3; cited by S. M. Dubrovsky, Stolypinskaia zemel'naia reforma (Moscow, 1963), p. 203.

Among the fifty provinces included in the 1905 land statistics, nine in the west had no communal tenure, or virtually none. The statistics of the Ministry of the Interior (MVD) on departures from the commune, therefore, covered only the remaining provinces with the exception of the Don Region (which had special Cossack land arrangements) and Arkhangelsk. The forty MVD provinces included Stavropol, which had not been surveyed in 1905 and where the extent of communal tenure was unknown though substantial.

The statistics indicate that the number of appropriations by May 1, 1915, was 22 percent of the original number of communal households in the forty provinces. ${ }^{21}$ By that time, according to other sources, the number of communal households in these provinces had risen to 10.2 million. ${ }^{22}$ The total of 2.5 million separations is taken here as a departure of 24 percent of the communal membership. These two widely cited ratios appear to be in general agreement and lead to the conclusion that about a quarter of the peasantry had left the commune.

21. TsSK, Statisticheskii eshegodnik 1915, sec. 6:1.

22. Oganovsky, Revoliutsiia naoborot, p. 99; Dubrovsky, Stolypinskaia zemel'naia reforma, p. 205. 
On the eve of the reform three-fourths of the peasantry had been in communes; and if one-fourth had left, then only half might appear to remain. But since the one-fourth was a ratio of communal peasants only, and notas some writers have indicated -of the entire peasantry, more than half would have remained in communes. ${ }^{23}$ If the automatic juridical conversions are considered as departures, then the movement out of the commune can be shown as 41 percent. And if this figure is added to the 23 percent sector of the peasantry that was originally outside of the commune, it could seem that two-thirds of the countryside was noncommunal at the end of the decade.

The inclusion of the automatic juridical conversions, however, is a questionable procedure. Even the official statistics on the results of the law of June 14,1910, took account only of those households actually receiving certificates either as individuals or as members of communes that had applied for group certification. The number of households in communes involved involuntarily through the certification of individual members-the number used to arrive at the 41 percent-was provided in a rough estimate made by an alarmed populist. ${ }^{24}$ The accuracy of the figure, however, is less at issue than the legitimacy of counting these households among those who left the commune. According to contemporaries, the communes considered in law as automatically converted to fixed hereditary tenure generally continued in fact to hold and to redistribute the land exactly as before. ${ }^{25}$

The sale of individual property in allotment land that had been in communal tenure required proof of appropriation or documents of certification, and only those who had them held full personal property rights. Personal or individual tenure of allotment land (lichnoe, edinolichnoe vladenie nadel'noi zemlei), however, was juridically distinct from the ownership of private property (chastnaia sobstvennost'), though the two are frequently taken together as forms of personal property. ${ }^{28}$ Allotment land remained under class restrictions with limitations on sale, mortgage, and extent of holding right up to 1917, while private land could be held by anyone. Since the uncertified peasants in the converted communes continued communal practices and did not

23. Liashchenko, in both his earlier work (p. 492), where Dubrovsky is cited, and in his Istoriia narodnogo khoziaistva SSSR, 3rd ed., 2 vols. (Leningrad, 1952-56), 2:265, speaks of 24 percent of the "general number of households in the forty provinces of European Russia" rather than of communal households. Similar usage appears in François-Xavier Coquin, La Révolution russe (Paris, 1962), p. 11, and in Alexandre Michelson, L'essor economique de la Russie avant la guerre de 1914 (Paris, 1965), p. 149. Communal households listed for the provinces (without Stavropol) in 1905 numbered 9.1 million, and the total number of peasant households in these provinces was 10.6 million.

24. Oganovsky, Revoliutsiia naoborot, p. 99.

25. Manuilov, "Noveishee zakonodatel'stvo," p. 252.

26. Under the law of May 29, 1911, allotment land undergoing reorganization with a household's privately owned land could be reclassified as private property under certain conditions. 
have an individual right to sell allotment land, the immediate practical consequences of juridical conversions are problematic. The degree of social and economic change actually effected in the countryside during this period is obscured by counting these paper transactions as separations. ${ }^{27}$

Returning then to the 2.5 million documented separations, there is a question about whether they actually indicate the departure of 24 percent of the communal peasantry. The problem concerns the number of communal households said to exist in 1915. The figure of 10.2 million cited earlier for the forty MVD provinces appears to be the only one in use, yet it is possible that it is erroneous and has been employed inappropriately. ${ }^{28}$ If so, calculations based on it (showing 24 or 41 percent of departures) are invalid. Until archival investigation resolves the question, the possibility of its accuracy cannot be dismissed. If correct, however, the figure creates new statistical difficulties. Though it is given as the number of households of "communal peasants" (obshchinniki), the way it is used indicates that it represents all households deriving from those in communes in 1905 rather than households actually still in communes. Yet the figure of 10.2 million households is too low to account for the natural increase of the original communal households by 1915 . On the other hand, if the 10.2 million stands for households remaining in communes, the 24 percent is still not correct. The 2.5 million separations would mean a departure of slightly under 20 percent $\left(\frac{2.5}{10.2+2.5}\right)^{29}$

The 22 percent rate of separation provided in the MVD statistics for appropriations is equally questionable. The procedure followed here was to compare the number of appropriations completed by May 1915 in the forty provinces with the number of communal households in thirty-nine provinces in $1905 . .^{30}$ Use of the 1905 data indicates a more substantial exodus than is

27. Dubrovsky and Liashchenko, both of whom referred in earlier works to the 41 percent figure as "impressive," were to drop it in later accounts; yet it still finds currency elsewhere.

28. The figure $10,176,100$ is used by Dubrovsky in the 1963 edition of his work, p. 205, in a table for which an archival reference is supplied (TsGIAL, fond 1291, op. $121,1916 \mathrm{~g}$., d. 75, 1. 4). The same number, however, appears in the 1926 edition, p. 108, in a similar table taken from Oganovsky (Revoliutsiia naoborot, p. 99). Oganovsky does not cite a source for the figure, but his text indicates that he may have used a number for communal households that applied to 1912 (given as $10,167,100$, possibly with a transposed digit), although his table was said to show the dissolution of the commune by May 1, 1915. The figure for 1912 tallies closely with an estimate calculated by Lositsky (Raspadeniia obshchiny, pp. 40-41) for the number of households at the end of 1912 deriving from prereform communal households. The fact that Oganovsky has used Lositsky's estimates elsewhere strengthens the possibility that this is the ultimate source of the figure.

29. The higher rate would amount to stating that since one household which had departed from a five-household commune constituted one-quarter of the remaining four, then 25 percent had departed.

30. Since only percentages were provided, it is necessary to return to the 1905 sta- 
warranted. Separations occurred over a period in which the population was growing rapidly-with an average annual increase of slightly over 2 percent up to $1915 .^{31}$ Allowance must be made for the appearance of new households when calculating the effects of departures. ${ }^{32}$ The number of households existing at the end of the period is essential to an evaluation of the statistics on separations.

In the forty-seven provinces of European Russia covered by the agricultural census of 1916 there were 15.5 million peasant households. ${ }^{33}$ The same provinces in 1905 contained 12.1 million peasant households. Estimated at the average rate of growth, the three noncommunal provinces missing from the later data add another 300,000 households for a total of 15.8 million peasant households in 1916. (See appendix 1.) Unfortunately, the census did not distinguish communal from noncommunal households. Between 1906 and 1916 the natural increase in households (which the government had previously tried to check through the commune) was augmented by more frequent family divisions. Separations from the commune and consolidations of land accelerated such divisions. ${ }^{34}$ The resulting economically irrational fragmentation of landholdings led the agricultural administration to seek legislative restrictions.

Under the circumstances, not every separation from the commune meant a reduction in the number of communal households. Since family divisions were more apt to occur among communal households, it is likely that there were relatively more households in 1916 stemming from the communal households of 1905 than from the noncommunal households. ${ }^{35}$ Yet even at the earlier 77 percent ratio, there would have been 12.2 million households deriving from the 1905 communal households by 1916 . If 2.5 million of these

tistics for absolute numbers to determine the procedure. No allowance was made for communal househelds in Stavropol, but its 44,000 appropriations were included with separations (as in the calculation yielding the 24 percent). The rate of separation drops slightly for the thirty-nine comparable provinces when Stavropol is omitted.

31. TsSK, Statisticheskii ezhegodnik 1915, sec. 1:58.

32. Failure to provide for growth was shading statistical reports within just a few years, for example N. A. Rubakin's Rossiia $v$ tsifrakh (St. Petersburg, 1912), p. 167.

33. Predvaritel'nye itogi Vserossiiskoi sel'skokhoziaistvennoi perepisi 1916 goda, pt. 1: Evropeiskaia Rossiia (Petrograd, 1916), pp. 462-624. The census covered rural households "of peasant type" (see pp. xxxiii-xxxiv). Grodno, Kovno, and Kurland were not included.

34. Kofod, Russkoe zemleustroistvo, p. 22. In one sample covering some 17,000 households on allotment land, 323 households had split after consolidation into 752 households; another 429 had divided before consolidation; see Glavnoe upravlenie zemleustroistva i zemledeliia, Zemleustroennye khoziaistva (Petrograd, 1915), p. 15. For the economic consequences see part 8.

35. The overall increase in households in the six comparable noncommunal provinces was 22.5 percent as compared with 29 percent in the remaining provinces, but because the data on western households were incomplete in both 1905 and 1916 the rate here can be only suggestive. 
Chart 2. Relative Size of Communal Sectors, 1905 and 1916

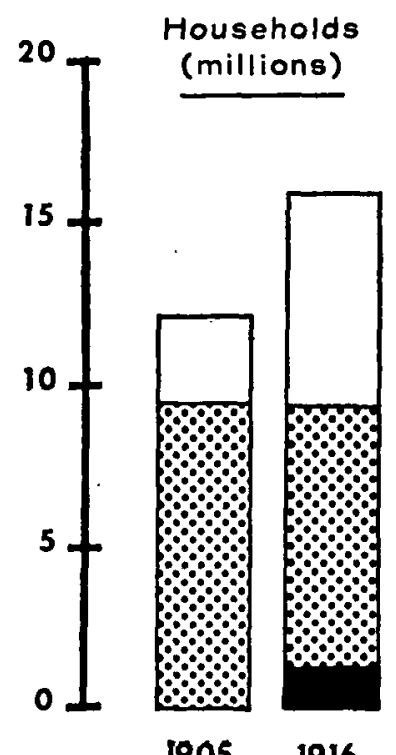

19051916

\author{
Land (ten million desiatins)

Allotment Land All Peasant Land
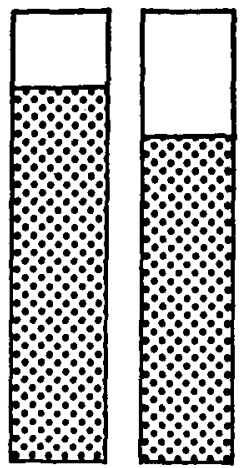

1916

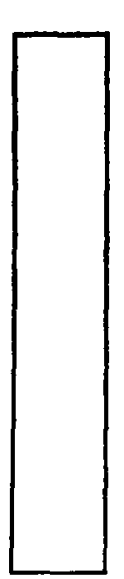

1905

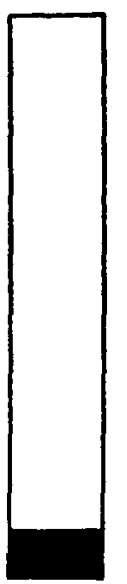

1916
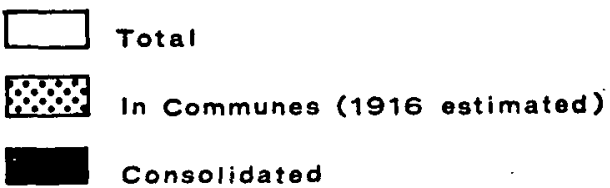

had departed from communes, 9.7 million-or 61 percent of all peasant households-would have remained communal. ${ }^{36}$ The inadequate nature of the data makes any inference here highly tentative, but the conclusion suggested is reinforced by analysis of the movement of allotment land out of communal tenure under the reform.

In 1905 the peasantry in the fifty provinces held 139 million desiatins of allotment land, including 115.4 million ( 83 percent) in communes. By 1916 a total of 16.3 million desiatins ( 14 percent of communal allotment land) had been individualized through appropriations and certifications. ${ }^{37}$ Another 100,000 desiatins had been taken out of communal tenure through consolidations in the Don Region and Astrakhan. ${ }^{38}$ The 99 million desiatins remaining in communes was 71 percent of the allotment land held by the entire peas-

36. If there were still 10.2 million households in communes in the forty provinces in 1915, there should be added to these 400,000 in the Don Region and Arkhangelsk. The total of 10.6 million communal households would have amounted to 67 percent of all households in the fifty provinces. As noted, however, the 10.2 million figure is highly uncertain.

37. Statisticheskii spravochnik, pp. 26-27.

38. Pershin, Uchastkovoe zemlepol'zovanie, pp. 50-51. 
antry. Some of this may have been taken out of communal tenure through consolidations that took place after May 1911 without prior separation of title. The allotment land involved in all consolidations from mid-1911 up to 1917 came to 7.5 million desiatins, but the shares of noncommunal land and of previously appropriated communal land cannot be determined. Yet even if the entire amount is deducted from communal land, two-thirds of all allotment land and the greater part of all land (allotment and nonallotment). held by the peasantry by 1915 remained in communes. ${ }^{39}$

Examination of the imperfect statistical materials, then, though it confirms an appreciable movement out of communal tenure, indicates that most of the peasants and their land remained under the communal system right up to the Revolution. Assessment of the impact of the reform on the communal structure has been complicated by statistical inadequacies, and perhaps by the unconscious influence of varying attitudes and expectations concerning the development of Russian capitalism. The question that still invites attention is why more peasants did not leave the commune once the Stolypin reform opened a way, given the drawbacks of the system and historical evidence of its declining vitality. But this is another topic. ${ }^{40}$ Obviously the war that began in 1914 affected later developments, but the earlier pattern calls for explanation.

The attack on the commune was essentially a clearing operation; a successful outcome depended on reconstruction. Only where the land had been consolidated and separated physically from that of others was it possible for the peasant to introduce changes or follow an independent crop cycle. In the course of the reform decade 10 percent of the entire rural population was transferred to consolidated individual farms. Yet not all of this was at the expense of communal households or land. The total amount of land consolidated by 1917 ( 16 million desiatins), including lands acquired from the Peasant Land Bank and the state, was 9 percent of all land held by the peasantry at the time. Only a quarter of the consolidations ( 2 or 3 percent of all peasant households) were of the officially favored khutor type where the peasant dwelling was moved from the village to the fields; and many consolidators still retained a part of their land in communal tenure. ${ }^{41}$

39. In 1905 the peasantry, through individual or group purchases, owned almost 25 million desiatins of private land (about one-fourth of all private land). This included 3.7 million desiatins owned by communes. By 1915 peasant nonallotment holdings had increased by 9.6 million desiatins, and the total area of land held by the peasantry was approximately 173 million desiatins.

40. See the comments of I. D. Koval'chenko and N. B. Selunskaia in Istoriia SSSR, 1971, no. 5, p. 211, and Koval'chenko's observations in Istoriia SSSR, 1973, no. 2, p. 72.

41. About 7 percent of the land included under consolidations actually remained in communal usage. See Pershin, Uchastkovoe zemlepol'zovanie, pp. 50-51. This was pri- 
Recently several reconsiderations of the prerevolutionary period have challenged views prevailing in their respective historiographic environments. The extent of capitalist development in rural Russia has been the subject of vigorous Soviet debate, and the "amelioration thesis" has been questioned in the West. On the one hand there is new evidence of agrarian backwardness, and on the other there is new emphasis on urban social instability. ${ }^{42}$

The commune is a critical link between the economics of the countryside and the politics of the cities. It has been suggested that the disintegration of the commune under the Stolypin reform released the excess rural labor force and produced a sudden influx into the towns, creating pressures that were mounting rapidly before the outbreak of the war. ${ }^{43}$ Even a relatively minor movement out of the countryside, however, could have had major impact on the equilibrium of the far smaller urban sector. The extent to which this movement was the result of the reform program or a response to a broader socioeconomic complex may still be questioned, and the answer is relevant to an evaluation of the success of this early attempt at a planned economy.

marily pasture and meadow, most difficult to individualize because of the short supply and the expense of conversion to stall-keeping.

42. A. M. Anfimov, Krupnoe pomeshchich'e khoziaistvo Evropeiskoi Rossii (Moscow, 1969) ; Leopold Haimson, "The Problem of Social Stability in Urban Russia, 1905-1917," Slavic Review, 23, no. 4 (December 1964): 619-42, and 24, no. 1 (March 1965): 1-22.

43. Haimson, "Problem of Social Stability," pp. 634-36. The effects of the 1910 legislation are particularly noted here. The four-year economic revival period witnessed an urban population growth of close to 500,000 precisely when the bulk of the 500,000 certifications were issued, yet most of the 2 million appropriations had been completed before 1910. Land-sale statistics are frequently used as evidence of proletarianization, but contrary conclusions have been drawn from them. Cf. M. S. Simonova, "Mobilizatsiia krest'ianskoi nadel'noi zemli v period Stolypinskoi agrarnoi reformy," Materialy po istorii sel'skogo khoziaistva i krest'ianstva SSSR, vol. 5 (Moscow, 1962), and V. A. Kosinsky, Osmovnye tendentsii v mobilizatsii zemel'noi sobstvennosti $i$ ikh sotsial'no-ekonomicheskie faktory (Prague, 1925). 
Appendix 1. Communal Tenure, 1905-1916

\begin{tabular}{|c|c|c|c|c|c|c|c|c|c|c|}
\hline \multirow[b]{3}{*}{ Province } & \multicolumn{6}{|c|}{ Peasant Households } & \multicolumn{4}{|c|}{ Allotment Land (desiatins) } \\
\hline & \multicolumn{3}{|c|}{$1905^{a}$} & \multicolumn{2}{|c|}{$1916^{b}$} & \multirow{2}{*}{$\begin{array}{l}\text { Separated } \\
\text { from } \\
\text { Communes } \\
\text { by } 1916^{c}\end{array}$} & \multicolumn{3}{|c|}{$1905^{a}$} & \multirow{2}{*}{$\begin{array}{l}\text { Separated } \\
\text { from } \\
\text { Communes } \\
\text { by } 1916^{c}\end{array}$} \\
\hline & $\begin{array}{l}\text { Total } \\
\text { Listed }\end{array}$ & $\begin{array}{c}\text { In } \\
\text { Communes }\end{array}$ & $\%$ & $\begin{array}{l}\text { Total } \\
\text { Listed }\end{array}$ & $\begin{array}{c}\% \\
\text { Increase }\end{array}$ & & Total & $\begin{array}{c}\text { In } \\
\text { Communes }\end{array}$ & $\%$ & \\
\hline Arkhangelsk & 55,149 & 53,741 & 97 & 69,746 & 26 & - & 334,848 & 322,138 & 96 & - \\
\hline $\begin{array}{l}\text { Arknangeisk } \\
\text { Astrakhan }\end{array}$ & 72,099 & 72,099 & 100 & 198,062 & $\begin{array}{r}20 \\
175\end{array}$ & $\overline{3}, 590$ & $2,354,887$ & $2,354,887$ & 100 & 50,083 \\
\hline Bessarabia & 284,636 & 79,849 & 28 & 430,876 & 51 & 14,033 & $1,864,023$ & $\begin{array}{r}2, J 34,007 \\
762,542\end{array}$ & 41 & 147,432 \\
\hline Chernigov & 367,369 & 189,350 & 51 & 391,533 & 7 & 25,992 & $2,329,209$ & $1,247,432$ & 54 & 143,456 \\
\hline Don Region & 330,548 & 330,317 & 100 & 445,283 & 35 & - & $9,847,439$ & $9,845,610$ & 100 & - \\
\hline Ekaterinoslav & 270,824 & 268,680 & 99 & 482,912 & 78 & 156,013 & $2,531,076$ & $2,517,540$ & 99 & 979,962 \\
\hline Estonia & 11,605 & - & - & 36,166 & 216 & - & 394,070 & - & - & - \\
\hline Grodno & 91,692 & - & - & $117.732^{*}$ & $28^{*}$ & -2 & $1,517,164$ & - & - & 57 \\
\hline Iaroslav & 198,619 & 198,286 & 100 & 214,371 & 8 & 29,575 & $1,420,617$ & $1,414,655$ & 99 & 199,706 \\
\hline Kaluga & 172,015 & 171,435 & 100 & 197,763 & 15 & 90,989 & $1,391,630$ & $1,388,623$ & 100 & 645,422 \\
\hline Kazan & 374,574 & 374,574 & 100 & 445,011 & 19 & 33,941 & $3,205,412$ & $3,205,314$ & 100 & 166,122 \\
\hline Kharkov & 364,100 & 339,172 & 93 & 424,783 & 17 & 121,483 & $2,663,142$ & $2,517,860$ & 94 & 604,283 \\
\hline Kherson & 294,297 & 274,468 & 93 & 417,038 & 42 & 138,371 & $2,291,208$ & $2,005,846$ & 87 & 809,029 \\
\hline Kiev & 383,503 & 32,808 & 9 & 652,194 & 70 & 15,961 & $2,106,781$ & 153,877 & 7 & 78,021 \\
\hline Kostroma & 239,787 & 239,775 & 100 & 303,795 & 27 & 34,898 & $2,136,373$ & $2,136,214$ & 100 & 259,998 \\
\hline Kovno & 110,400 & - & - & $141,753^{*}$ & $28^{*}$ & - & $1,610,379$ & - & - & - \\
\hline Kurland & 28,281 & - & - & $36,313^{*}$ & $28 *$ & - & 930,845 & - & — & 一 \\
\hline Kursk & 335,271 & 233,762 & 70 & 380,995 & 14 & 129,246 & $2,455,363$ & $1,463,298$ & 60 & 496,577 \\
\hline Latvia & 22,498 & - & - & 68,411 & 198 & - & $1,158,892$ & - & - & - \\
\hline Minsk & 213,924 & - & - & 312,726 & $\begin{array}{r}170 \\
46\end{array}$ & - & $1,945,998$ & - & - & - \\
\hline Mogilev & 198,283 & 159,644 & 80 & 248,603 & 25 & 109,405 & $1,619,346$ & $1,283,565$ & 79 & 843,937 \\
\hline Moscow & 210,570 & 210,556 & $\begin{array}{r}00 \\
100\end{array}$ & 281,409 & 34 & 87,070 & $1,584,564$ & $1,580,711$ & 100 & 432,573 \\
\hline Nizhegorod & 264,711 & 263,664 & 100 & 318,805 & $\begin{array}{l}34 \\
20\end{array}$ & 48,095 & $1,970,159$ & $1,960,319$ & 100 & 219,346 \\
\hline Novgorod & 214,183 & 213,950 & 100 & 260.531 & 22 & 35,438 & $2,886.931$ & $2,880,322$ & 99 & 405,726 \\
\hline Olonets & 59,323 & 58,247 & 98 & 71,672 & 21 & 8,062 & $3,859,922$ & $3,856,277$ & 100 & 158,262 \\
\hline Orenburg & 228,057 & 228,057 & 100 & 343,763 & 51 & 23,380 & $10,668,218$ & $10,668,218$ & 100 & 352,287 \\
\hline Orlov & 287,166 & 257,658 & 90 & 331,395 & 16 & 116,837 & $2,009,101$ & $1,758,640$ & 87 & 534,160 \\
\hline Penza & 240,960 & 232,423 & 96 & 281,549 & 17 & 60,677 & $1,814,031$ & $1,749,896$ & 96 & 282,334 \\
\hline
\end{tabular}


Appendix 1-Continued

\begin{tabular}{|c|c|c|c|c|c|c|c|c|c|c|}
\hline \multirow[b]{3}{*}{ Province } & \multicolumn{6}{|c|}{ Peasant Households } & \multicolumn{4}{|c|}{ Allotment Land (desiatins) } \\
\hline & \multicolumn{3}{|c|}{$1905^{a}$} & \multicolumn{2}{|c|}{$1916^{b}$} & \multirow{2}{*}{$\begin{array}{l}\text { Separated } \\
\text { from } \\
\text { Communes } \\
\text { by } 1916^{c}\end{array}$} & \multicolumn{3}{|c|}{$1905^{a}$} & \multirow{2}{*}{$\begin{array}{c}\text { Separated } \\
\text { from } \\
\text { Communes } \\
\text { by } 1916^{c}\end{array}$} \\
\hline & $\begin{array}{c}\text { Total } \\
\text { Listed }\end{array}$ & $\begin{array}{c}\text { In } \\
\text { Communes }\end{array}$ & $\%$ & $\begin{array}{l}\text { Total } \\
\text { Listed }\end{array}$ & $\begin{array}{c}\% \\
\text { Increase }\end{array}$ & & Total & $\begin{array}{c}\text { In } \\
\text { Communes }\end{array}$ & $\%$ & \\
\hline$\overline{\text { Perm }}$ & 520,466 & 520,466 & 100 & 674,847 & 30 & 26,892 & $8,337,535$ & $8,228,764$ & 100 & 319,679 \\
\hline Podolia & 458,764 & 1,630 & - & 573,687 & 3 & - & $1,754,187$ & 8,929 & - & - \\
\hline Poltava & 446,876 & 80,176 & 18 & 475,619 & 6 & 12,290 & $2,195,458$ & 320,945 & 15 & 52,608 \\
\hline Pskov & 158,917 & 158,917 & 100 & 203,115 & 28 & 56,905 & $1,460,552$ & $1,460,552$ & 100 & 460,519 \\
\hline Riazan & 280,906 & 273,402 & 97 & 336,920 & 20 & 63,495 & $1,885,044$ & $1,790,738$ & 96 & 223,128 \\
\hline St. Petersburg & 106,504 & 104,114 & 98 & 130,327 & 22 & 16,577 & $1,030,952$ & $1,019,229$ & 99 & 131,902 \\
\hline Samara & 337,111 & 334,232 & 99 & 517,186 & 53 & 180,105 & $6,712,499$ & $6,593,051$ & 99 & $2,193,981$ \\
\hline Saratov & 351,126 & 350,686 & 100 & 433,575 & 23 & 100,893 & $3,348,968$ & $3,339,533$ & 100 & 632,920 \\
\hline Simbirsk & 244,870 & 241,234 & 98 & 304,558 & 24 & 59,858 & $1,658,265$ & $1,634,427$ & 93 & 302,022 \\
\hline Smolensk & 215,930 & 214,587 & 99 & 267,193 & 24 & 74,777 & $1,936,107$ & $1,922,271$ & 99 & 570,994 \\
\hline Tambov & 405,953 & 393,605 & 97 & 484,121 & 19 & 112,632 & $2,848,238$ & $2,749,786$ & 97 & 448,478 \\
\hline Taurida & 132,876 & 122,341 & 92 & 239,784 & 80 & 80,219 & $1,957,532$ & $1,548,084$ & 79 & 764,754 \\
\hline Tula & 214,063 & 182,562 & 85 & 245,968 & 15 & 56,460 & $1,350,252$ & $1,130,377$ & 84 & 225,093 \\
\hline Tver & 302,888 & 299,795 & 99 & 338,416 & 12 & 73,405 & $2,641,579$ & $2,583,439$ & 99 & 490,331 \\
\hline Ufa & 318,748 & 311,880 & 98 & 499,682 & 57 & 48,374 & $6,251,777$ & $6,059,015$ & 99 & 333,158 \\
\hline Viatka & 482,470 & 478,736 & 99 & 591,020 & 22 & 27,662 & $7,717,969$ & $7,701,333$ & 100 & 337,042 \\
\hline Vilna & 94,420 & 443 & - & 57,971 & 61 & - & $1,278,677$ & 7,559 & 1 & - \\
\hline Vitebsk & 138,566 & 73,456 & 53 & 189,375 & 37 & 30,332 & $1,593,147$ & 711,187 & 45 & 214,975 \\
\hline Vladimir & 243,011 & 236,472 & 97 & 267,036 & 10 & 28,595 & $2,162,546$ & $2,107,806$ & 98 & 139,329 \\
\hline Vologda & 238,039 & 230,265 & 97 & 286,812 & 20 & 21,643 & $3,699,372$ & $3,650,465$ & 99 & 191,120 \\
\hline Volynia & 292,387 & 5,359 & 2 & 290,648 & 1 & - & $2,298,861$ & 62,009 & 3 & - \\
\hline Voronezh & 388,570 & 383,122 & 99 & 474,950 & 22 & 80,491 & $3,746,442$ & $3,687,100$ & 98 & 478,877 \\
\hline Total & $12,297,905$ & $9,479,995$ & 77 & $15,788,000$ & 28 & $2,434,663$ & $138,767,587$ & $115,390,383$ & 83 & $16,319,683$ \\
\hline
\end{tabular}

* Estimated.

Sources: a Statistika zemlevladeniia $1905 \mathrm{~g} .:$ Svod dannykh po 50 guberniiam Evropeiskoi Rossii, pp. xxxii-xxxiii. bPredvaritel'nye itogi V serossiiskoi sel'skokhoziaistvennoi perepisi 1916 goda, pt. 1: Evropeiskaia Rossiia, pp. 462-624. cStatisticheskii spravochnik, pt. 1, pp. $26-27$. 
Appendix 2. Consolidations by 1917

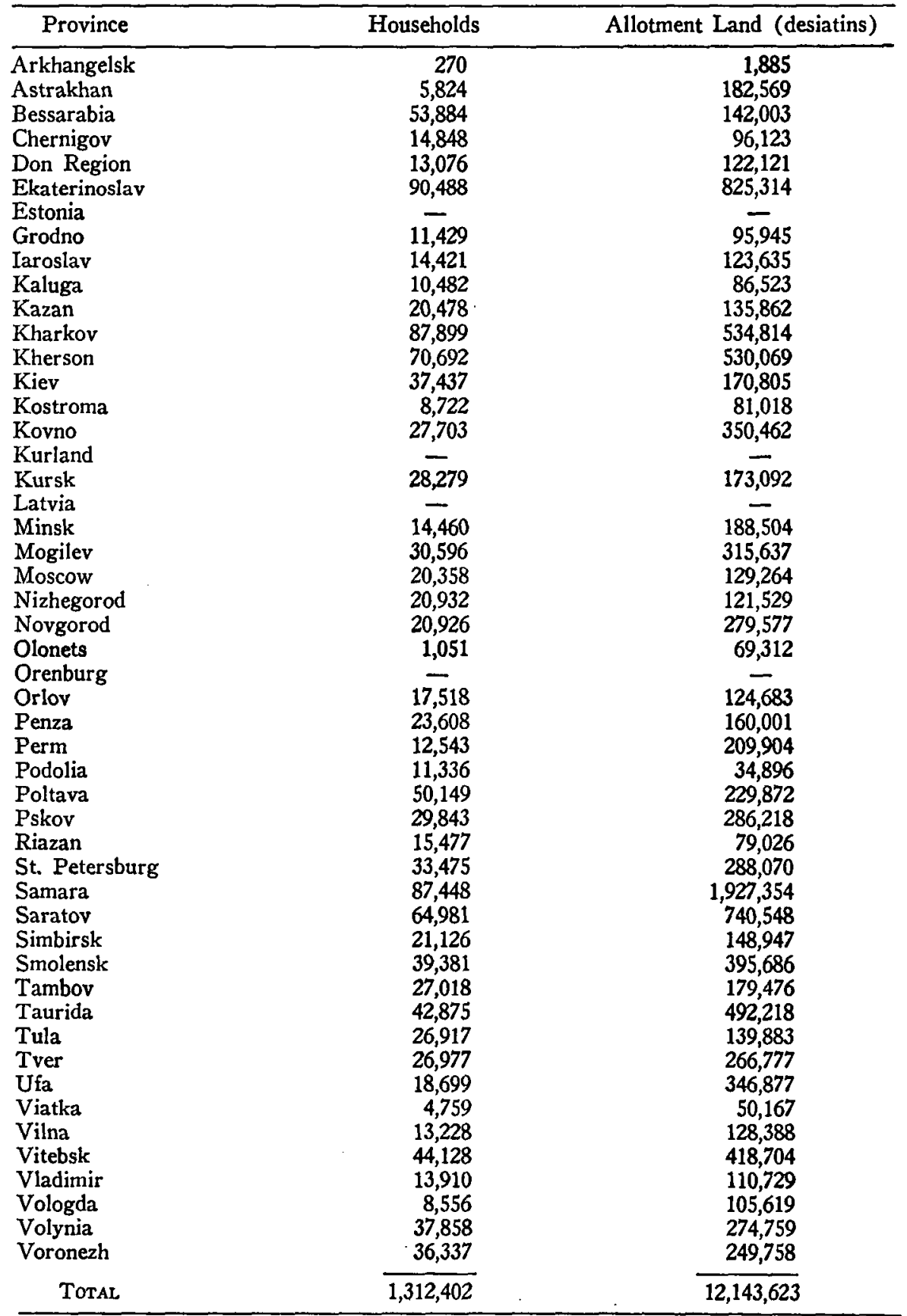

Source: Pershin, Uchastkovoe zemlepol'zovanie, pp. 48-51. Orenburg and the Baltic states were not included in the work of the Land Organization Commissions. 